JURNAL AL BAYAN: JURNAL JURUSAN PENDIDIKAN BAHASA ARAB

p-ISSN 2086-9282 | e-ISSN 2549-1229

\title{
Mobile Devices for Arabic Learning in Junior High Schools: The Teachers' Perspective
}

\author{
Azkia Muharom Albantani ${ }^{1}$, Imam Fitri Rahmadi ${ }^{2}$ \\ ${ }^{1}$ Arabic Education Study Program Universitas Islam Negeri Syarif Hidayatullah Jakarta, Indonesia \\ ${ }^{2}$ STEM Education Study Program Johannes Kepler Universität Linz, Austria
}

\section{Article History:}

Received : May 13, 2020

Revised : June 25, 2020

Accepted : July 30, 2020

Published : December 01, 2020

\section{Keywords:}

Arabic Learning; Junior High

Schools; Mobile Devices; Teachers'

Perspective

*Correspondence Address: azki@uinjkt.ac.id

\begin{abstract}
The present study aims to identify teachers' perceptions of mobile devices use in Arabic learning at junior high schools. Employed a qualitative method with a case study, 24 Arabic language teachers from various junior high schools in the South Tangerang City involved in this study selected by using a random sampling method. Based on the teacher perspectives, the results of the study reveal that the use of mobile devices facilitates students in understanding Arabic lessons and increase their motivation for learning. Time limitations and large classroom sizes were obstacles that decrease teachers' interest to integrate mobile devices into classroom activities. Reading is by far the main language skill taught by teachers and there is a less focus on productive skills such as speaking and writing. The students have less attention and motivation for learning Arabic while the teachers have attempted to deal with this problem by several measures. The characteristic of Arabic language differs from each context. However, whether for inside or outside classroom activities, active methods are of particular importance for Arabic learning. Arabic teaching and learning practices facilitated by mobile devices require careful planning for a successful implementation lead to more active and effective learning of Arabic.
\end{abstract}

\section{Introduction}

Nowadays, smart technologies ease daily social communication. Communicating with friends, families, or colleagues now is possible without having a face-to-face meeting. Mobile devices open up the possibilities for everyone, providing everything on their fingertip. Surprisingly, either adults or children are able to use the devices agilely. It uses were not only for entertainment but also for business, office administration, and learning. Interestingly, the devices also can be used as instructional media in the classroom.

Mobile devices are emerging potential tools for delivering effective instructions 
in formal ${ }^{1}$ and informal ${ }^{2}$ learning settings ${ }^{3}$. The appropriate uses of mobile devices in the classroom were highly motivating students and stimulate a positive perception toward mobile devices for learning. While unfortunately there are some schools ban the uses, research showed that support from school management for the use of mobile devices in formal school systems enhancing student's learning achievements. ${ }^{4}$ Mobile devices include smartphones, tablets, Personal Data Assistances (PDAs) or might be laptops and desktop computers. Nevertheless, it was argued that the truly mobile devices are smartphones, tablets, and PDAs, which fit in the pocket and are easy to operate whenever and wherever every day. ${ }^{5}$

The emerging of mobile devices in today's world challenges teachers to be able to integrate it into teaching and learning practices. Additionally, teachers should encourage students to use their mobile devices for learning rather than for entertainment so the students could learn ubiquitously whenever and wherever they wanted. It is evident that mobile devices are attracting everyone from variety of economical background. ${ }^{6}$ The devices are now more affordable and accessible to prospective customers, thus everyone be able to buy it conveniently. In fact, according to the Kemp's survey, over $90 \%$ of the adult population in Indonesia carries at least a mobile device. ${ }^{7}$ Smartphones by far are the most popular mobile devices reaching $60 \%$. Furthermore, accessing the Internet is the main uses spending more than 8 hours and 30 minutes on average on a daily basis.

There is a rapid development of foreign language learning applications. Various Android and iOS-based application provider platforms provide many of these applications for free or paid mode. Students can easily access many applications of

${ }^{1}$ Yu-Liang Ting, "The Pitfalls of Mobile Devices in Learning: A Different View and Implications for Pedagogical Design," Journal of Educational Computing Research 46, no. 2 (March 1, 2012): 119-134.

2 Ann Jones et al., "Using Mobile Devices for Learning in Informal Settings: Is It Motivating?" (Presented at the IADIS International Conference on Mobile Learning, Dublin: IADIS Press, 2006), 251255, accessed May 12, 2020, http://www.iadisportal.org/digital-library/using-mobile-devices-for-learningin-informal-settings-is-it-motivating.

${ }^{3}$ Yao-Ting Sung, Kuo-En Chang, and Tzu-Chien Liu, "The Effects of Integrating Mobile Devices with Teaching and Learning on Students' Learning Performance: A Meta-Analysis and Research Synthesis," Computers \& Education 94 (March 1, 2016): 252-275.

${ }^{4}$ Ros Walker, "I Don't Think I Would Be Where I Am Right Now". Pupil Perspectives on Using Mobile Devices for Learning," Research in Learning Technology 21 (September 6, 2013), accessed May 12, 2020, https://journal.alt.ac.uk/index.php/rlt/article/view/1471.

5 Alan B. Craig, Understanding Augmented Reality: Concepts and Applications (Amsterdam: Morgan Kaufmann, 2013).

${ }^{6}$ Syarief Oebaidillah, "Gawai Dan Konsentrasi Belajar, Tantangan Mendidik Siswa Zaman Now," October 10, 2018, https://mediaindonesia.com/read/detail/189938-gawai-dan-konsentrasi-belajartantangan-mendidik-siswa-zaman-now. 
foreign language learning independently as learning resources for learning languages, such as Busuu, Lingua, and other applications. ${ }^{8}$ The existing applications appeal for Arabic teaching and learning practices. Exploring the use, particularly in Arabic learning and instruction, is of further interest of investigation. By doing so in the future, it helps to understand the best practices and implications for effective Arabic lesson.

The use of mobile devices for learning purposes at junior high school students requires teacher supervision in the classroom as well as parents supervision at home. Between teachers and parents have a shared important role to manage the time and content on the use of the devices for learning. ${ }^{9}$ It is inevitable using mobile devices in today's educational practices while its use should be managed appropriately. The better the management, the higher result achieved. Based on the mentioned issues, it is of importance to study the use of mobile devices in learning Arabic at junior high school in South Tangerang City.

The present study aims to investigate mobile devices use in junior high school for teaching and learning of Arabic. The main finding of this study reveals the current state of Arabic learning and instruction facilitated by mobile devices in Indonesia. Moreover, the benefits and drawbacks are also discussed in the next section. The remaining section of this article addresses other issues such as essential Arabic skills, students' attention and motivation, and the characteristic of the Arabic language. Perhaps this study is fruitful for putting forward best practices and further implications of mobile devices integration in Arabic learning.

\section{Method}

This study employed a qualitative method with a case study ${ }^{10}$ to identify teacher's perceptions about learning Arabic at the junior high school level in the City of South Tangerang. The study was used an interview to collect data related to the studied issues, namely mobile devices use for Arabic learning, advantages and disadvantages of using

\footnotetext{
${ }^{7}$ Simon Kemp, “Digital 2019: Indonesia,” DataReportal - Global Digital Insights, 2019, accessed February 11, 2020, https://datareportal.com/reports/digital-2019-indonesia.

8 Azkia Muharom Albantani, "Optimalisasi Aplikasi Busuu Dalam Pembelajaran Bahasa Arab Mandiri,” Arabic: Journal of Arabic Studies 3, no. 1 (2018): 1-10.

${ }^{9}$ Yudha Manggala P Putra, "Regulasi Pembatasan Ponsel Pada Anak," Republika, March 6, 2018, https://www.republika.co.id/berita/kolom/fokus/18/03/06/p54zba284-regulasi-pembatasan-ponsel-padaanak.

${ }^{10}$ Unika Prihatsanti, Suryanto Suryanto, and Wiwin Hendriani, "Menggunakan Studi Kasus Sebagai Metode Ilmiah Dalam Psikologi,” Buletin Psikologi 26, no. 2 (December 3, 2018): 126. 
mobile devices for learning Arabic, essential Arabic language skills, students' attention and motivation, and the characteristic of Arabic language. There were 24 Arabic language teachers from various junior high schools engaged in this study selected by using a random sampling method. Correspondingly, the research data were analysed descriptively.

\section{Result and Discussion}

\section{Teachers Profile}

The interviews revealed that 4 teachers (17\%) are graduates of the Arabic Language and Literature Department, 8 teachers (33\%) are graduates of the Arabic Language Department, 8 teachers (33\%) are graduates of the Department of Islamic Education, and 4 teachers $(17 \%)$ are graduates of the Islamic Cultural History Department. This shows that not all Arabic teachers were graduated from Arabic Language Education. However, it is important to note that Arabic teachers who graduated from the other departments should be prepared seriously in terms of developing their competences to appropriately teach Arabic. ${ }^{11}$ The interview results were presented in the following sections with regard to the issues along with the discussions in an integrative way. The findings were also critically discussed respecting relevant previous studies.

\section{Mobile Devices Use for Arabic Learning}

The interview results show that not all Arabic teachers use mobile devices during teaching and learning activities. A teacher stated that the use of mobile devices were very limited in learning and the teachers tend to teach by using conventional learning methods such as lectures and questions-answers methods. The teacher argues that he was reluctant to use mobile devices for teaching because the classroom is fairly large (an average of 40 students per class) lead to an assumption that is ineffective to use. However, in fact, the use of learning media, on the contrary, can help Arabic teachers deal with teaching and learning in a large classroom with many students.

${ }^{11}$ Abdul Munip, “Tantangan Dan Prospek Studi Bahasa Arab Di Indonesia," al Mahāra: Jurnal Pendidikan Bahasa Arab 5, no. 2 (January 3, 2020): 303-318. 
The other teachers stated their habit of using several digital platforms in order to evaluate learning by giving quizzes to students after learning certain materials. ${ }^{12}$ In addition, the teacher also delivered learning material by using multimedia in the classroom to engage students in the classroom and motivate them to involve in Arabic learning. The media facilitate students to memorize daily vocabulary in Arabic easily. Moreover, there are several teachers who use Instagram social media in the process of learning Arabic. It started by the teacher that uploads a simple Arabic conversation video. The students and even Internet users in general can learn Arabic conversation through the video afterwards.

The new school curriculum in Indonesia that is called Kurikulum 2013 requires teachers to actively use instructional media and teach in active ways. ${ }^{13}$ However, other teachers tend to use PowerPoint regularly for teaching and learning Arabic. Unluckily, some teachers were unable to operate laptops. Occasionally, the teacher gives flexibility to students to use mobile devices in Arabic learning activities in the classroom. However, many students use mobile devices for other purposes instead of learning. This is the future challenge for teachers to design technology-supported classroom activities effectively. ${ }^{14}$ New approaches and media should be taken into consideration of designing and conducting classroom in the future.

Some schools have a policy to control students using mobile devices in schools. While learning Arabic conducted by a classical method such as lectures and questionsanswers. The teachers were merely using textbooks and student worksheets, or sometimes using teaching aids already available in the classroom. Teaching and learning facilitated with mobile devices require teachers to be creative in preparing learning material on an online application accessible from the devices. Alternatively, they can utilise Arabic materials that have been uploaded on the online application by other users, for example, using learning material on a YouTube channel.

\footnotetext{
${ }^{12}$ Andarusni Alfansyur and Mariyani Mariyani, 'Pemanfaatan Media Berbasis ICT 'Kahoot' Dalam Pembelajaran PPKN Untuk Meningkatkan Motivasi Belajar Siswa,” Bhineka Tunggal Ika 6, no. 2 (2019): 208-216.

13 Alinurdin Alinurdin and Imam Fitri Rahmadi, "Implementasi Kurikulim 2013 SMP Di Kota Tangerang Selatan Tahun Pelajaran 2017/2018," Jurnal Pendidikan Kewarganegaraan 5, no. 2 (October 14, 2018): 117.

${ }^{14}$ Azkia Muharom Albantani, "Implementasi Kurikulum 2013 Pada Pembelajaran Bahasa Arab Di Madrasah Ibtidaiyah," Arabiyat: Jurnal Pendidikan Bahasa Arab dan Kebahasaaraban 2, no. 2 (December 31, 2015): 178-191.
} 
Learning activities in the classroom remains to require creativity and innovation from the teachers so the students can learn effectively. A combination of classical and modern learning methods is highly important to be used by the teacher that results in better students' understanding of the content and higher students' motivation to learn. The use of an online dictionary application is also highly recommended so the students can easily find the meaning of an Arabic vocabulary that going to be studied. Students could obtain the dictionary applications from the app provider located in Playstore for Androidbased devices and Appstore for iOS-based devices. The teacher should recommend students for using Google Translate to find the meaning of vocabulary, not merely for finding the meaning of a paragraph.

There is a moderate perspective from junior high school teachers on the integration of mobile devices in Arabic teaching and learning activities in the classroom. While some teachers reluctant to use the devices, the other teachers were using it regularly for delivering meaningful instruction and conducting a convenient evaluation by using social media and games. Teachers play a significant role in the integration of the devices so examples and best practices should be disseminated to some teachers who were not in favor of using mobile devices for learning. Some great implementations are available from the previous studies, for instance, using WhatsApp to activate students-tostudents interaction of the Arabic language, ${ }^{15}$ augmenting the reality of Arabic learning environment by using flashcards, ${ }^{16}$ and utilising variety mobile applications or social media. ${ }^{17}$ Likewise, having a school policy that supports the integration is critical to the best implementation.

\section{Advantages and Disadvantage of Using Mobile Devices for Learning Arabic}

The use of information and communication technology in learning Arabic ideally facilitates students to understand learning materials because of its possibilities to be used anywhere and anytime. While a classroom lesson is limited to 2x40 minutes per week. Thus, the use of technology can be a solution to the limitations of class hours. A teacher

\footnotetext{
${ }^{15}$ Ibtehal Mahmoud Aburezeq and Fawzi Fayez Ishtaiwa, "The Impact of WhatsApp on Interaction in an Arabic Language Teaching Course," International Journal of Arts \& Sciences 6, no. 3 (2013): 165.

16 Nurkhamimi Zainuddin and Rozhan M. Idrus, "The Use of Augmented Reality Enhanced Flashcards for Arabic Vocabulary Acquisition," in 2016 13th Learning and Technology Conference (L T), 2016, 1-5.

${ }^{17}$ Saleh Al-Shehri, "Mobile Learning in the Arab World: Contemporary and Future Implications," chapter, Interdisciplinary Mobile Media and Communications: Social, Political, and Economic Implications, last modified 2014, accessed May 12, 2020, www.igi-global.com/chapter/mobile-learning-inthe-arab-world/111712.
} 
stated that the use of technology for learning Arabic at a secondary level has not been clearly benefiting. However, the most important action is the teacher's effort in introducing Arabic to students so they are interested in learning Arabic.

The use of various learning resources provided on the Internet, for instance, can be used as an example of hiwar (conversations) that students would be able to hear and understand Arabic vocabulary in ease. Alternative activities obtained from online sources that applicable to classroom teaching and learning are also a solution to stimulate students' interests in learning, for example, language games or others. The lack of teacher skills in using digital learning media is an evident factor that leads to a lower quality of technology-based Arabic language learning. It conditions decrease the natural process of learning and student engagement. ${ }^{18}$ Therefore, the teachers should be trained for integrating smart technologies appropriately into the classroom.

The difference level in the duration of students understanding the lesson becomes another obstacle for learning Arabic facilitated with mobile devices. Some students conveniently understand the learning material whilst others require more time to understand the materials. In addition, some mobile learning applications were not familiar with the contents containing Arabic letters. This is a challenge for app developers to enable Arabic letters more accessible and useable on the application. Perhaps it supports Arabic to be introduced to a wider community as English.

The benefits and drawbacks of using mobile devices for educational practices of Arabic in the mind of teachers are blurred. It seems beneficial, however, it has some downsides to some extent. The time limitation and the huge classroom size are considered as obstacles that decrease teachers' interest to integrate mobile devices into classroom activities. Developing Arabic teachers' technological pedagogical content knowledge (TPACK) ${ }^{19}$ could be a solution to better integration of mobile devices into Arabic learning. By doing so, it improves teachers' awareness toward technological

${ }^{18}$ Azkia Muharom Albantani, Ahmad Madkur, and Abd. Rozak, "Foreign Language Instruction in Madrasah Ibtidaiyah in the Technological Age: The Teachers' Voices," in Proceedings of the 2nd International Conference on Islam, Science and Technology (ICONIST 2019), Mataram, West Nusa Tenggara, Indonesia: Atlantis Press, 2020), accessed April 21, 2020, https://www.atlantispress.com/article/125935083.

19 Matthew J. Koehler and Punya Mishra, "What Happens When Teachers Design Educational Technology? The Development of Technological Pedagogical Content Knowledge," Journal of Educational Computing Research 32, no. 2 (March 2005): 131-152. 
resources for teaching with regard to pedagogical aspects and leaning contents. ${ }^{20}$ The TPACK is not only new knowledge but a recent framework for developing 21 first century teachers as well. ${ }^{21}$ Besides, this limitation issue of using mobile devices should be taken into further consideration by school principals and stakeholders respectively.

\section{Essential Arabic Language Skills}

The result of the interview reveals four essential Arabic language skills need to be mastered by students comprehensively due to the interconnectedness of the skills. Those namely istimah (listening) as the ability in listening to Arabic, kalam (speaking) as the ability for speaking Arabic, qiraah (reading) as the ability to read Arabic texts, and kitabah (writing) as the ability of Arabic writing. Unfortunately, in the Arabic teaching and learning processes, teachers more likely to enforce students in the skills of understanding Arabic texts (fahm al-maqru) since the final grade of learning is a written test. This case is a special issue for the 9th-grade students in order to pass the national exam with a good grade. As for students in grade 7, conversational skills in Arabic have a greater portion of teaching and learning activities in the classroom.

Conversational skills in Arabic have an important function as a means of oral communication. The students, therefore, are expected to master Arabic not only in theory but also in practice. As a result, receptive and productive skills can be well mastered by students although it is at a simple level. It is evidence that practice makes perfect. This theory surprisingly works while learning language with particular respect on the active activities such as speaking and writing. A simple form of sentence is normal to start producing the more complicated ones.

Hijaiyah illiteracy is a common problem occurs in junior high schools. With this condition, students were unable to read the Qur'an. Learning hijaiyah letters in the form of Arabic vocabulary needs to be well formulated in order to eradicate and reduce the level of hijaiyah illiteracy. ${ }^{22}$ In other words, the teachers have to Arabic learning skills integrated with listening, speaking, reading, and writing skills. In addition, Arabic elements such as vocabulary, letter sounds, and simple Arabic grammar must also be

${ }^{20}$ Imam Fitri Rahmadi, "Technological Pedagogical Content Knowledge (TPACK): Kerangka Pengetahuan Guru Abad 21," Jurnal Pendidikan Kewarganegaraan 6, no. 1 (March 25, 2019): 65.

${ }^{21}$ Punya Mishra and Matthew J. Koehler, "Technological Pedagogical Content Knowledge: A Framework for Teacher Knowledge," Teachers college record 108, no. 6 (2006): 1017.

${ }^{22}$ Muhammad Nurman, "Pemberantasan Buta Huruf Arab (Huruf Hijaiyah) Pada Ibu-Ibu Rumah Tangga Di Desa Bayan Kecamatan Bayan Kabupaten Lombok Utara," El-Tsaqafah: Jurnal Jurusan PBA 16, no. 1 (2017): 76-92. 
taught in an integrated manner. Thus, students can master Arabic language skills more comprehensively.

There are shared essential language skills between Arabic and English. Listening (istimah), speaking (kalam), reading (qiraah), and writing (kitabah) are the cornerstones of a language. Unfortunately, reading is by far language skills that mainly taught by teachers in junior high schools and less portion on productive skills such as speaking and writing. Meanwhile, by a reading lesson, it is possible to integrate between receptive and productive skills simultaneously. ${ }^{23}$ A specific learning strategy, such as mind-mapping method, could be a smooth transition from respective to productive skills development. ${ }^{24}$ Those two previous cases were cases of learning English, and it seems possible to be implemented in Arabic learning as well.

\section{Students' attention and Motivation}

The interview results showed that the teachers have been trying to increase students' interest and motivation in learning Arabic. Take as examples, teachers explain the importance of Arabic and keep update with recent technologies. Arabic is a language associated with Muslims and its religious worship. The development of science and technology had also developed during the heyday of Islam. In the process of learning Arabic, the teachers ought to utilise the right strategies and methods in order to increase student interest in learning Arabic. One example is using language games. There are a plethora of language games that can be used by the teacher, such as drawing pictures, puzzles, role playing, and others. Besides being fun and interesting, language games potential to train students to think in Arabic. ${ }^{25}$

Furthermore, harnessing a singing method in Arab looks benefit to increase students' interest and motivation in learning Arabic. As a result, students do not only consider Arabic as a religious language but also as an international communication language such as English and other languages. It is also important for teachers to give an understanding to students that Arabic is the identical language as a Muslim. This can be

${ }^{23}$ Harits Masduqi, "Integrating Receptive Skills and Productive Skills into a Reading Lesson," Proceeding of the International Conference on Teacher Training and Education 2, no. 1 (November 23, 2016): 507-511.

${ }^{24}$ Tran Thanh Thu, "Using Mind-Mapping as A Transition from Receptive to Productive Skills for Second-Degree Learners," VNU Journal of Foreign Studies 35, no. 1 (February 18, 2019): 155-173.

${ }^{25}$ Asnul Uliyah and Zakiyah Isnawati, "Metode Permainan Edukatif Dalam Pembelajaran Bahasa Arab," Shaut Al-'Arabiyah 7, no. 1 (2019): 31-43. 
done through Al-Qur'an reading and writing as regular activities at schools in order to increase students' interest and motivation in learning Arabic.

The teacher in each Arabic lesson should also give the impression that Arabic is not a difficult language to learn. This is a challenge for Arabic teachers to be able to teach Arabic as simply as possible so that the Arabic is highly understandable for students. ${ }^{26}$ Pedagogical, as well as technological innovations about learning methods, are alternative ways to increase students' interest and motivation in learning Arabic. Arabic teachers in several schools use the tamyiz method in learning Arabic. The method focuses on translating the Arabic language through singing activities that are recognised by students as effective method to increase their understanding of Arabic significantly.

Students have less attention and motivation for learning Arabic while teachers have attempted to deal with this problem by several measures. Innovative ways of teaching Arabic that have been done by some teachers including games, drawing pictures, and singing should be adopted by the other teachers. With particular respect to games in education or so-called serious games, those are potential to provide amusement for learning. ${ }^{27}$ Students could be highly motivated by integrating serious games during the learning processes in an individual or collaborative gameplay. ${ }^{28}$ Other ways or methods thus are critical to be further explored and investigated in terms of better facilitating teaching and learning Arabic in junior high schools.

\section{The Characteristics of Arabic Language}

The interview results show that some teachers apply a distinctive Arabic learning model. Some schools have students who are also students in an Islamic boarding school located nearby. These kinds of students should be peer tutors in order to help regular students to understand Arabic subject. In addition, fresh-graduate teachers have some advantages in teaching Arabic by fun learning activities learned from their study in universities. Likewise, the art skills possessed by the teacher also play an important role in creative teaching and learning, for example by using singing as a learning approach. ${ }^{29}$

\footnotetext{
${ }^{26}$ Muhammad Zainuri, "Perkembangan Bahasa Arab Di Indonesia," Tarling : Journal of Language Education 2, no. 2 (July 31, 2019): 231-248.

${ }^{27}$ David R. Michael and Sandra L. Chen, Serious Games: Games That Educate, Train, and Inform (Muska \& Lipman/Premier-Trade, 2005).

${ }^{28}$ Rosemary Garris, Robert Ahlers, and James E. Driskell, "Games, Motivation, and Learning: A Research and Practice Model,” Simulation \& gaming 33, no. 4 (2002): 441-467.

${ }^{29}$ Muhandis Azzuhri, "Metode Dan Media Pembelajaran Bahasa Arab Berbasis Internet Di Era Teknologi Informasi," Insania : Jurnal Pemikiran Alternatif Kependidikan 14, no. 3 (2009): 348-445.
} 
In some schools, there is a policy that requires students to have an Arabic conversation in the morning before starting learning in the classroom. This was carried out routinely 2 times per week. Through these activities, the schools attempt to create an Arabic-speaking environment so the students are more interested in learning Arabic. Learning Arabic outside the classroom is also a positive activity stimulate students' interest in learning Arabic. It is thematic and contextual teaching based on the surrounding environments. For example, the school garden could be used as a place for learning Arabic. Students could be able to learn various Arabic vocabularies about various equipments in the park. ${ }^{30}$

The program of remembering two vocabularies every day is a breakthrough that should be appreciated in order to increase the number of vocabulary mastered by students. The two vocabularies are then formed into informative sentences. This program is carried out in collaboration with student learning groups assisted by OSIS and Arabic language teachers. The use of Arabic as the language of instruction in learning is one of the teacher's efforts to get students actively communicate in Arabic. This must be done even though mixed with Indonesian. Additionally, an Arabic vocabulary card media with illustrations can be an alternative medium for learning Arabic.

The characteristic of Arabic language differs from each context. However, whether inside or outside the classroom, active methods are of particular importance for Arabic learning. ${ }^{31}$ Learning from what has been done by the teachers includes singing, morning conversation, remembering short vocabulary daily to teach Arabic have to be continued in the future. The peer-tutors strategy is also good practice so the students would be able to learn and improve their Arabic language skills and competencies collaboratively.

This study reflects on what has been done by teachers in terms of harnessing mobile devices for Arabic learning in junior high schools. The findings show interrelated successful factors as well as actors in integrating the devices for learning. Teachers supported by school principals play an important role in this case. Meaning that the teachers' attempt in using smart technologies for learning should also be supported by supportive policies from the school principals. The supports that are needed not only

\footnotetext{
${ }^{30}$ Fathur Rohman, "Strategi Pengelolaan Komponen Pembelajaran Bahasa Arab," Arabiyat : Jurnal Pendidikan Bahasa Arab dan Kebahasaaraban 1, no. 1 (June 28, 2014): 63-78.

${ }^{31}$ Muhammad Yusuf and Ismail Suardi Wekke, "Active Learning on Teaching Arabic for Special Purpose in Indonesian Pesantren," Procedia-Social and Behavioral Sciences 191 (2015): 137-141. 201 | Jurnal Al Bayan: Jurnal Jurusan Pendidikan Bahasa Arab, 12 (2): 191-207 (2020)
} 
about some advanced equipment but it is regarding improving teacher knowledge to use technology as well. As a result, it would improve teachers' beliefs and knowledge ${ }^{32}$ of using mobile devices as powerful teaching tools in the classroom. ${ }^{33}$

Regarding the mobile devices, it is evident from the teacher perspectives that the use of mobile devices facilitates the students in understanding Arabic lessons and increases their motivation for learning. However, some pedagogical barriers appear such as the sort learning duration while in contrast there are many students in the classroom. This also leads to the minimum implementation of active Arabic teaching methods. Meanwhile, conducting for example Arabic conversation is a good attempt of implementing active learning method, it is kind of learning by doing. ${ }^{34}$ Other examples of popular and successful active teaching and learning approaches that may be integrated into Arabic learning include teaching with case studies and problem-based learning, where students confront the complexities of a language issue or puzzle and reasoning through potential solutions. ${ }^{35}$

It is evident from the findings that mobile devices have not been sufficiently wellintegrated for learning Arabic although the devices massively used day-to-day by students for various activities in a variety of ways. Consequently, as the implication of this study, this could be considered into future endeavors so that Arabic learning could be more suitable with the characteristics of millennial generation in the digital age. In particular to the teachers, which should be prepared to teach mobile-based Arabic, learning in schools. ${ }^{36}$ Additionally, pedagogical innovations in Arabic learning in terms of providing meaningful learning processes through smart educational technologies may be investigated in future studies. ${ }^{37}$ It means that technological innovations on teaching and learning of Arabic could be of further research interest as well.

\footnotetext{
${ }^{32}$ Anita Hoy, Heather Davis, and Stephen Pape, "Teacher Knowledge and Beliefs," Handbook of Educational Psychology 2 (January 1, 2006): 715-738.

33 Peggy A. Ertmer and Anne T. Ottenbreit-Leftwich, "Teacher Technology Change: How Knowledge, Confidence, Beliefs, and Culture Intersect," Journal of Research on Technology in Education 42, no. 3 (March 2010): 255-284.

34 Jeffrey Lantis, Kent Kille, and Matthew Krain, "The State of the Active Teaching and Learning Literature," The International Studies Encyclopedia 10 (January 1, 2010).

35 Jana Hackathorn et al., "Learning by Doing: An Empirical Study of Active Teaching Techniques," Journal of Effective Teaching 11, no. 2 (2011): 40-54.

${ }^{36}$ Gesta Lestari, Ana Mahbubah, and Mokhammad Fadhil Masykuri, "Pembelajaran Bahasa Arab Digital Dengan Menggunakan Media Padlet Di Madrasah Aliyah Billingual Batu," vol. 4, 2019, $238-244$.

37 Zuli Dwi Rahmawati, "Penggunaan Media Gadget Dalam Aktivitas Belajar Dan Pengaruhnya Terhadap Perilaku Anak," TA'LIM : Jurnal Studi Pendidikan Islam 3, no. 1 (January 17, 2020), accessed June 30, 2020, http://www.e-jurnal.unisda.ac.id/index.php/talim/article/view/1910.
} 
The stakeholders are expected to pay greater attention to support the continued development of Arabic learning. It seems that the teachers are in need of various training in developing digital technology-based learning media in order to teach in a more creative and innovative manner. ${ }^{38}$ Teachers play a significant role in learning processes so that related stakeholders should take the training into account seriously. The recent modified TPACK framework such as TPACK-21, ${ }^{39}$ E-TPCK, ${ }^{40}$ and TPACK-SAMR ${ }^{41}$ models could be used as the training model. ${ }^{42}$ By doing so, the teachers would be able to actively and appropriately play around specific technology and pedagogy with suitable Arabic content.

\section{Conclusion}

To put it in a nutshell, the diversity of Arabic teaching backgrounds influences the successful learning of Arabic. The teacher's competences issues are in need of great solutions through the participation of teachers in various training to improve their quality of Arabic teaching. Furthermore, the effective use of technology in terms of facilitating students' understanding of Arabic lessons and increasing their interest and motivation in learning is another concern. Learning Arabic by using information and communication technology requires careful planning so that the learning could be successfully and effectively conducted.

\section{Acknowledgment}

The authors would like to acknowledge Arabic language teachers from several junior high schools in South Tangerang City, Banten, Indonesia who have voluntarily participated in this study.

${ }^{38}$ Mahyudin Ritonga, Alwis Nazir, and Sri Wahyuni, "Pembelajaran Bahasa Arab Berbasis Teknologi Informasi Dan Komunikasi Di Kota Padang," Arabiyat : Jurnal Pendidikan Bahasa Arab dan Kebahasaaraban 3, no. 1 (2016).

39 Teemu Valtonen et al., "TPACK Updated to Measure Pre-Service Teachers' Twenty-First Century Skills," Australasian Journal of Educational Technology 33, no. 3 (July 24, 2017), accessed June 30, 2020, https://ajet.org.au/index.php/AJET/article/view/3518.

${ }^{40}$ Charoula Angeli and Andri Christodoulou, "Developing Pre-Service Teachers' Technological Pedagogical Content Knowledge with e-TPCK," in Handbook of Research on TPACK in the Digital Age (IGI Global, 2019), 350-364.

${ }^{41}$ Nyarai Tunjera and Agnes Chigona, "Teacher Educators' Appropriation of TPACK-SAMR Models for 21st Century Pre-Service Teacher Preparation:," International Journal of Information and Communication Technology Education 16, no. 3 (July 2020): 126-140. 


\section{References}

Aburezeq, Ibtehal Mahmoud, and Fawzi Fayez Ishtaiwa. "The Impact of WhatsApp on Interaction in an Arabic Language Teaching Course." International Journal of Arts \& Sciences 6, no. 3 (2013): 165.

Albantani, Azkia Muharom. "Implementasi Kurikulum 2013 Pada Pembelajaran Bahasa Arab Di Madrasah Ibtidaiyah." Arabiyat: Jurnal Pendidikan Bahasa Arab dan Kebahasaaraban 2, no. 2 (December 31, 2015): 178-191.

_. "Optimalisasi Aplikasi Busuu Dalam Pembelajaran Bahasa Arab Mandiri." Arabic: Journal of Arabic Studies 3, no. 1 (2018): 1-10.

Albantani, Azkia Muharom, Ahmad Madkur, and Abd. Rozak. "Foreign Language Instruction in Madrasah Ibtidaiyah in the Technological Age: The Teachers' Voices." In Proceedings of the 2nd International Conference on Islam, Science and Technology (ICONIST 2019). Mataram, West Nusa Tenggara, Indonesia: Atlantis Press, 2020. Accessed April 21, 2020. https://www.atlantispress.com/article/125935083.

Alfansyur, Andarusni, and Mariyani Mariyani. "Pemanfaatan Media Berbasis ICT 'Kahoot' Dalam Pembelajaran PPKN Untuk Meningkatkan Motivasi Belajar Siswa." Bhineka Tunggal Ika 6, no. 2 (2019): 208-216.

Alinurdin, Alinurdin, and Imam Fitri Rahmadi. "Implementasi Kurikulim 2013 SMP Di Kota Tangerang Selatan Tahun Pelajaran 2017/2018." Jurnal Pendidikan Kewarganegaraan 5, no. 2 (October 14, 2018): 117.

Al-Shehri, Saleh. "Mobile Learning in the Arab World: Contemporary and Future Implications." Chapter. Interdisciplinary Mobile Media and Communications: Social, Political, and Economic Implications. Last modified 2014. Accessed May 12, 2020. www.igi-global.com/chapter/mobile-learning-in-the-arab-world/111712.

Angeli, Charoula, and Andri Christodoulou. "Developing Pre-Service Teachers' Technological Pedagogical Content Knowledge with e-TPCK." In Handbook of Research on TPACK in the Digital Age, 350-364. IGI Global, 2019.

Azzuhri, Muhandis. "Metode Dan Media Pembelajaran Bahasa Arab Berbasis Internet Di Era Teknologi Informasi." Insania : Jurnal Pemikiran Alternatif Kependidikan 14, no. 3 (2009): $348-445$.

Craig, Alan B. Understanding Augmented Reality: Concepts and Applications. Amsterdam: Morgan Kaufmann, 2013.

Ertmer, Peggy A., and Anne T. Ottenbreit-Leftwich. "Teacher Technology Change: How Knowledge, Confidence, Beliefs, and Culture Intersect." Journal of Research on Technology in Education 42, no. 3 (March 2010): 255-284.

Garris, Rosemary, Robert Ahlers, and James E. Driskell. "Games, Motivation, and Learning: A Research and Practice Model.” Simulation \& gaming 33, no. 4 (2002): 441-467.

${ }^{42}$ Imam Fitri Rahmadi, Eti Hayati, and Aulia Nursyifa, "Comparing Pre-Service Civic Education Teachers' TPACK Confidence Across Course Modes,” Research in Social Sciences and Technology 5, no. 2 (May 17, 2020): 113-133. 
Hackathorn, Jana, Erin Solomon, K.L. Blankmeyer, Rachel Tennial, and A.M. Garczynski. "Learning by Doing: An Empirical Study of Active Teaching Techniques." Journal of Effective Teaching 11, no. 2 (2011): 40-54.

Hoy, Anita, Heather Davis, and Stephen Pape. "Teacher Knowledge and Beliefs." Handbook of Educational Psychology 2 (January 1, 2006): 715-738.

Jones, Ann, Kim Issroff, Eileen Scanlon, Gill Clough, Patrick McAndrew, and Canan Blake. "Using Mobile Devices for Learning in Informal Settings: Is It Motivating?" 251-255. Dublin: IADIS Press, 2006. Accessed May 12, 2020. http://www.iadisportal.org/digital-library/using-mobile-devices-for-learning-ininformal-settings-is-it-motivating.

Kemp, Simon. "Digital 2019: Indonesia." DataReportal - Global Digital Insights, 2019. Accessed February 11, 2020. https://datareportal.com/reports/digital-2019indonesia.

Koehler, Matthew J., and Punya Mishra. "What Happens When Teachers Design Educational Technology? The Development of Technological Pedagogical Content Knowledge." Journal of Educational Computing Research 32, no. 2 (March 2005): 131-152.

Lantis, Jeffrey, Kent Kille, and Matthew Krain. "The State of the Active Teaching and Learning Literature.” The International Studies Encyclopedia 10 (January 1, 2010).

Lestari, Gesta, Ana Mahbubah, and Mokhammad Fadhil Masykuri. "Pembelajaran Bahasa Arab Digital Dengan Menggunakan Media Padlet Di Madrasah Aliyah Billingual Batu." 4:238-244, 2019.

Masduqi, Harits. "Integrating Receptive Skills and Productive Skills into a Reading Lesson." Proceeding of the International Conference on Teacher Training and Education 2, no. 1 (November 23, 2016): 507-511.

Michael, David R., and Sandra L. Chen. Serious Games: Games That Educate, Train, and Inform. Muska \& Lipman/Premier-Trade, 2005.

Mishra, Punya, and Matthew J. Koehler. "Technological Pedagogical Content Knowledge: A Framework for Teacher Knowledge." Teachers college record 108, no. 6 (2006): 1017.

Munip, Abdul. "Tantangan Dan Prospek Studi Bahasa Arab Di Indonesia." al Mahāra: Jurnal Pendidikan Bahasa Arab 5, no. 2 (January 3, 2020): 303-318.

Nurman, Muhammad. "Pemberantasan Buta Huruf Arab (Huruf Hijaiyah) Pada Ibu-Ibu Rumah Tangga Di Desa Bayan Kecamatan Bayan Kabupaten Lombok Utara." ElTsaqafah: Jurnal Jurusan PBA 16, no. 1 (2017): 76-92.

Oebaidillah, Syarief. "Gawai Dan Konsentrasi Belajar, Tantangan Mendidik Siswa Zaman Now," October 10, 2018. https://mediaindonesia.com/read/detail/189938gawai-dan-konsentrasi-belajar-tantangan-mendidik-siswa-zaman-now.

Prihatsanti, Unika, Suryanto Suryanto, and Wiwin Hendriani. "Menggunakan Studi Kasus Sebagai Metode Ilmiah Dalam Psikologi." Buletin Psikologi 26, no. 2 (December 3, 2018): 126. 
Putra, Yudha Manggala P. "Regulasi Pembatasan Ponsel Pada Anak." Republika, March 6, 2018. https://www.republika.co.id/berita/kolom/fokus/18/03/06/p54zba284regulasi-pembatasan-ponsel-pada-anak.

Rahmadi, Imam Fitri. "Technological Pedagogical Content Knowledge (TPACK): Kerangka Pengetahuan Guru Abad 21." Jurnal Pendidikan Kewarganegaraan 6, no. 1 (March 25, 2019): 65.

Rahmadi, Imam Fitri, Eti Hayati, and Aulia Nursyifa. "Comparing Pre-Service Civic Education Teachers' TPACK Confidence Across Course Modes." Research in Social Sciences and Technology 5, no. 2 (May 17, 2020): 113-133.

Rahmawati, Zuli Dwi. "Penggunaan Media Gadget Dalam Aktivitas Belajar Dan Pengaruhnya Terhadap Perilaku Anak." TA'LIM : Jurnal Studi Pendidikan Islam 3, no. 1 (January 17, 2020). Accessed June 30, 2020. http://www.ejurnal.unisda.ac.id/index.php/talim/article/view/1910.

Ritonga, Mahyudin, Alwis Nazir, and Sri Wahyuni. "Pembelajaran Bahasa Arab Berbasis Teknologi Informasi Dan Komunikasi Di Kota Padang." Arabiyat: Jurnal Pendidikan Bahasa Arab dan Kebahasaaraban 3, no. 1 (2016).

Rohman, Fathur. "Strategi Pengelolaan Komponen Pembelajaran Bahasa Arab." Arabiyat: Jurnal Pendidikan Bahasa Arab dan Kebahasaaraban 1, no. 1 (June 28, 2014): 63-78.

Sung, Yao-Ting, Kuo-En Chang, and Tzu-Chien Liu. "The Effects of Integrating Mobile Devices with Teaching and Learning on Students' Learning Performance: A MetaAnalysis and Research Synthesis." Computers \& Education 94 (March 1, 2016): 252-275.

Thu, Tran Thanh. "Using Mind-Mapping as A Transition from Receptive to Productive Skills for Second-Degree Learners." VNU Journal of Foreign Studies 35, no. 1 (February 18, 2019): 155-173.

Ting, Yu-Liang. "The Pitfalls of Mobile Devices in Learning: A Different View and Implications for Pedagogical Design.” Journal of Educational Computing Research 46, no. 2 (March 1, 2012): 119-134.

Tunjera, Nyarai, and Agnes Chigona. "Teacher Educators' Appropriation of TPACKSAMR Models for 21st Century Pre-Service Teacher Preparation:" International Journal of Information and Communication Technology Education 16, no. 3 (July 2020): 126-140.

Uliyah, Asnul, and Zakiyah Isnawati. "Metode Permainan Edukatif Dalam Pembelajaran Bahasa Arab.” Shaut Al-'Arabiyah 7, no. 1 (2019): 31-43.

Valtonen, Teemu, Erkko Sointu, Jari Kukkonen, Sini Kontkanen, Matthew C. Lambert, and Kati Mäkitalo-Siegl. "TPACK Updated to Measure Pre-Service Teachers' Twenty-First Century Skills." Australasian Journal of Educational Technology 33, no. 3 (July 24, 2017). Accessed June 30, 2020. https://ajet.org.au/index.php/AJET/article/view/3518.

Walker, Ros. “““I Don't Think I Would Be Where I Am Right Now”'. Pupil Perspectives on Using Mobile Devices for Learning." Research in Learning Technology 21 (September 6, 2013). Accessed May 12, 2020. https://journal.alt.ac.uk/index.php/rlt/article/view/1471. 
Yusuf, Muhammad, and Ismail Suardi Wekke. "Active Learning on Teaching Arabic for Special Purpose in Indonesian Pesantren." Procedia-Social and Behavioral Sciences 191 (2015): 137-141.

Zainuddin, Nurkhamimi, and Rozhan M. Idrus. "The Use of Augmented Reality Enhanced Flashcards for Arabic Vocabulary Acquisition.” In 2016 13th Learning and Technology Conference (L T), 1-5, 2016.

Zainuri, Muhammad. "Perkembangan Bahasa Arab Di Indonesia." Tarling: Journal of Language Education 2, no. 2 (July 31, 2019): 231-248. 